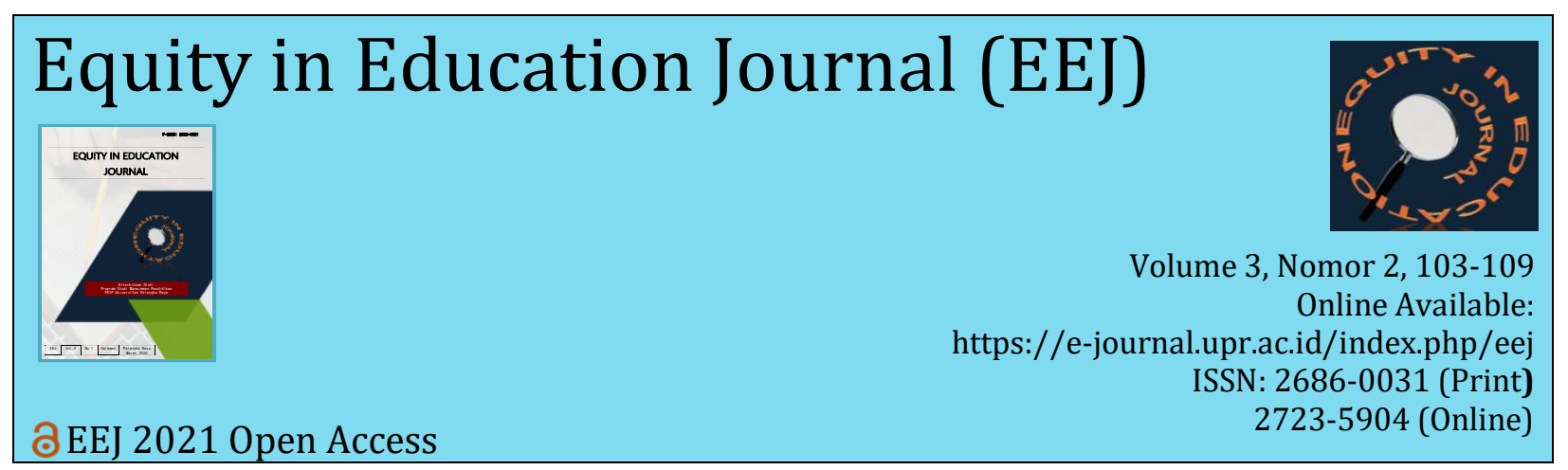

\title{
MANAJEMEN PROGRAM PENGUATAN PENDIDIKAN KARAKTER DI SMK KARSA MULYA PALANGKA RAYA
}

\author{
Jentry Lumban Batu*, Teti Berliani, Piter Joko Nugroho \\ FKIP, Universitas Palangka Raya, Palangka Raya
}

\begin{tabular}{ll}
\hline Info Artikel & \multicolumn{1}{c}{ Abstrak } \\
\hline Riwayat Artikel: & $\begin{array}{l}\text { Secara umum penelitian ini bertujuan untuk mendeskripsikan tentang } \\
\text { Manajemen Program Penguatan Pendidikan Karakter (PPK) di SMK Karsa }\end{array}$ \\
Diterima: 29 April 2021 & $\begin{array}{l}\text { Mulya Palangka Raya. Penelitian ini merupakan penelitian kualitatif dengan } \\
\text { rancangan studi kasus. Melalui teknik purposive sampling ditetapkan sumber data }\end{array}$ \\
Direvisi: 2 Agustus 2021 & dalam penelitian ini, meliputi: Kepala Sekolah, Tim Pengembang PPK, \\
& Koordinator Program PPK, Guru dan Tenaga Kependidikan. Teknik \\
Kata Kunci: & pengumpulan data melalui observasi, wawancara, dan studi dokumentasi. \\
Manajemen, Penguatan & Analisis data menggunakan pola interaktif data, meliputi: pengumpulan data, \\
Pendidikan Karakter, SMK & reduksi data, penyajian data, dan penarikan kesimpulan. Pengabsahan data \\
Karsa Mulya, Palangka Raya. & menggunakan teknik triangulasi sumber dan metode. Hasil penelitian \\
& menunjukkan bahwa pengelolaan program PPK di SMK Karsa Mulya terlaksana \\
& dengan efektif dalam menumbuhkembangkan karakter peserta didik, dan \\
& menjadikan SMK Karsa Mulya sebagai salah satu sekolah kejuruan swasta \\
& rujukan dalam pelaksanaan program PPK di Provinsi Kalimantan Tengah.
\end{tabular}

Korespondensi:

Jentry Lumban Batu*

FKIP, Universitas Palangka

Raya

E-mail:

jentry0897@gmail.com

\section{Abstract}

In general, this study aims to describe the Management of Character Education Strengthening Program (PPK) at SMK Karsa Mulya Palangka Raya. This research is a qualitative research with a case study design. Through purposive sampling technique, the data sources in this study were determined, including: Principal, PPK Development Team, PPK Program Coordinator, Teachers and Education Personnel. Data collection techniques through observation, interviews, and documentation studies. Data analysis used an interactive pattern of data, including: data collection, data reduction, data presentation, and drawing conclusions. Validation of data using triangulation of sources and methods. The results showed that the management of the PPK program at SMK Karsa Mulya was carried out effectively in developing student character, and making SMK Karsa Mulya as one of the referral private vocational schools in the implementation of PPK program in Central Kalimantan Province.

\section{PENDAHULUAN}

Undang-Undang Nomor 20 Tahun 2003 dalam Pasal 3 secara tegas menyatakan bahwa: "Pendidikan nasional berfungsi mengembangkan kemampuan dan membentuk watak serta peradaban bangsa yang bermartabat dalam rangka mencerdaskan kehidupan bangsa, bertujuan untuk berkembangnya potensi peserta didik agar menjadi manusia yang beriman dan bertaqwa kepada Tuhan Yang Maha Esa, berakhlak mulia, sehat, berilmu, cakap, kreatif, mandiri, dan menjadi waga negara yang demokratis serta bertanggung jawab". Mencermati tujuan dan fungsi pendidikan dalam perundangan tersebut nampak jelas bahwa tujuan dan fungsi dari diselenggarakannya pendidikan pada satuan pendidikan adalah untuk membentuk manusia 
Indonesia yang seutuhnya dengan meletakkan dasar kecerdasan, pengetahuan, kepribadian, akhlak mulia, serta keterampilan agar dapat hidup mandiri dan mengikuti pendidikan lebih lanjut. Pendidikan atau mendidik bukan hanya sebatas mentransfer ilmu saja, tetapi yang lebih utama adalah dapat mengubah atau membentuk karakter dan watak seseorang agar menjadi lebih baik, lebih sopan, dalam tataran etika dan estetika maupun perilaku dalam kehidupan sehari-hari sehingga proses pendidikan yang dilakukan harus dapat mewujudkan karakter peserta didik yang lebih baik dan bermartabat (Raharjo, 2010), sekaligus pula sebagai upaya dalam menghadapi berbagai tantangan pergeseran karakter yang dihadapi saat ini (Purwadhi, 2018).

Karakter berkaitan dengan konsep moral, sikap moral, dan perilaku moral (Lickona dalam Isnaini, 2016). Berdasarkan 3 (tiga) komponen tersebut dapat dinyatakan bahwa karakter yang baik didukung oleh pengetahuan tentang kebaikan, keinginan untuk berbuat baik, serta melakukan perbuatan yang baik (Maisaro dkk, 2018); dengan terwujudnya karakter peserta didik calon generasi penerus bangsa diharapkan mereka mampu secara mandiri meningkatkan dan menggunakan pengetahuannya, mengkaji dan menginternalisasi serta mempersonalisasi nilai-nilai karakter dan akhlak mulia sehingga terwujud dalam perilaku sehari-hari (Suwartini, 2017).

Peraturan Presiden (Perpres) Nomor 87 Tahun 2017 tentang Penguatan Pendidikan Karaker menyebutkan: "Penguatan Pendidikan Karakter yang selanjutnya disingkat dengan PPK adalah gerakan pendidikan di bawah tanggung jawab satuan pendidikan untuk memperkuat karakter peserta didik melalui harmonisasi olah hati, olah rasa, olah pikir, dan olah raga dengan pelibatan dan kerja sama antara satuan pendidikan, keluarga, dan masyarakat sebagai bagian dari gerakan Nasional Revolusi Mental(GNRM)". Dalam upaya tersebut satuan pendidikan diharapkan dapat melaksanakan pendidikan karakter secara bertahap dan disesuaikan dengan kebutuhan serta kondisi masing-masing sekolah (Kemendikbud, 2020). Pola pembentukan karakter pada setiap instansi pendidikan cukup bervariasi, hal tersebut disebabkan oleh adanya perbedaan peraturan yang telah diterapkan dengan kondisi masing-masing instansi pendidikan tersebut, karena setiap instansi memiliki pembinaan, pengasuh dan peserta didik yang berbeda (Maisaro dkk, 2018).

Salah satu sekolah kejuruan swasta di Kota Palangka Raya yang berhasil mengimplementasikan program PPK adalah SMK Karsa Mulya Palangka Raya. Program PPK bagi peserta didik di SMK Karsa Mulya Palangka Raya dilaksanakan melalui 3 (tiga) kegiatan yang dilaksanakan secara berkesinambungan dan kontinyu, melalui: (1) PPK terintegrasi dalam pembelajaran, (2) PPK terintegrasi dalam kegiatan ekstrakurikuler, dan (3) kegiatan pembiasaan diri. Kegiatan-kegiatan tersebut dilaksanakan dengan penuh komitmen dan konsisten dari seluruh personil sekolah yang terlibat guna mencapai tujuan program penguatan pendidikan karakter yang diharapkan. Hasil positif sejak dilaksanakannya program PPK tersebut adalah penghargaan yang diperoleh SMK Karsa Mulya sebagai salah satu sekolah kejuruan swasta di Kota Palangka Raya yang berhasil dalam mengimplementasikan PPK oleh Lembaga Penjaminan Mutu Pendidikan Provinsi Kalimantan Tengah (LPMP).

Penelitian ini bertujuan untuk mendeskripsikan tentang Manajemen Penguatan Pendidikan Karakter (PPK) di SMK Karsa Mulya Palangka Raya sebagai sekolah kejuruan swasta yang menjadi percontohan dalam mengimplementasikan progam PPK di Provinsi Kalimantan Tengah.

\section{METODE}

Penelitian ini merupakan penelitian kuantitatif dengan rancangan studi kasus, sebagaimana dinyatakan Creswell (dalam Sugiyono, 2014) sebagai suatu proses eksplorasi dan memahami makna perilaku individu dan kelompok, menggambarkan masalah sosial atau masalah kemanusiaan, dalam hal ini untuk memahami secara mendalam fenomena pengelolaan PPK di SMK Karsa Mulya Palangka Raya. Sumber data dalam penelitian ini meliputi: Kepala Sekolah, Koordinator PPK, Pembina Ekstrakurikuler, dan Guru-Guru yang terlibat dalam program PPK, yang ditetapkan melalui teknik purposive sampling. Teknik pengumpulan data melalui observasi, wawancara, dan studi dokumentasi. Analisis data menggunakan pola interaktif data dari Miles \& 
Huberman (2005), meliputi: pengumpulan data, reduksi data, penyajian data, dan penarikan kesimpulan. Pengabsahan data menggunakan teknik triangulasi sumber dan metode.

\section{HASIL DAN PEMBAHASAN \\ Perencanaan Program PPK}

Berdasarkan hasil temuan penelitian diketahui bahwa perencanaan dalam manajemen program PPK dilaksanakan untuk mempersiapkan terlaksananya 3 (tiga) macam bentuk kegiatan PPK, yaitu: PPK terintegrasi dalam pembelajaran, PPK terintegrasi dalam kegiatan ekstrakurikuler, dan pembiasaan diri. Proses perencanaan PPK dilaksanakan melalui tahapan sebagai berikut: (1) pembentukan Tim Pengembang PPK yang bertanggung jawab dalam pengelolaan program PPK secara keseluruhan sekaligus menetapkan nilai-nilai karakter yang akan dikembangkan pada kegiatan pembelajaran, ekstrakurikuler dan kegiatan pembiasan diri, (2) rapat koordinasi dengan melibatkan seluruh personil sekolah dan stakeholder terkait, (3) penetapan koordinator masing-masing program PPK, (3) penyusunan program kerja PPK, (4) penyiapan berbagai sumber daya sekolah, dan (5) penyiapan berbagai instrumen untuk melaksanakan pengawasan dan evaluasi pelaksanaan program PPK.

Nilai-nilai karakter yang akan diinternalisasikan pada ketiga bentuk kegiatan program PPK diadopsi dari 18 (delapan belas) nilai-nilai karakter yang telah ditetapkan oleh Kemendikbud. Pada konteks PPK terintegrasi dalam pembelajaran dilaksanakan melalui kegiatan sosialisasi nilai-nilai karakter kepada seluruh guru mata pelajaran, dan selanjutnya melaksanakan In House Training (IHT) untuk meningkatkan kompetensi guru dalam menyusun perangkat pembelajaran yang mengintegrasikan nilai-nilai karakter. Dalam pelaksanaan IHT pihak sekolah bekerjasama dengan pihak LPMP Provinsi Kalimantan Tengah dan para dosen dari Universitas Palangka Raya sebagai tenaga instruktur. Pada konteks PPK terintegrasi dalam kegiatan ekstrakurikuler, nilai-nilai karakter yang telah ditetapkan sekolah selanjutnya diinternalisasikan kepada seluruh kegiatan ekstrakurikuler yang sudah berjalan di sekolah seperti: kegiatan Pramuka dan ekstrakurikuler pilihan yang disesuaikan dengan minat dan hobi peserta didik, antara lain: Bola Voli, Basket, Tari Daerah, Band, dan Futsal, yang dilakukan oleh masing-masing pembina kegiatan ekstrakurikuler. Sedangkan pada konteks pembiasaan diri, nilai-nilai karakter tersebut sesungguhnya telah menjadi suatu kebiasaan atau budaya yang selama ini sudah terbangun di sekolah. Nilai-nilai budaya sekolah sebagai cerminan dari karakter tersebut antara lain dilaksanakan melalui rutinitas kegiatan ibadah pagi, disiplin dalam mengindahkan berbagai peraturan sekolah, menjaga keindahan dan kebersihan sekolah, kreatif dan mandiri serta saling toleransi.

Hasibuan (2011) menyatakan perencanaan merupakan suatu proses untuk menentukan rencana. Perencanaan berkaitan dengan rangkaian kegiatan yang akan dilaksanakan guna mencapai tujuan di masa yang akan datang secara efektif dan efisien (Sudjana, 2004; Mulyono, 2010). Berbagai kegiatan dalam program PPK yang dilaksanakan di sekolah ditujukan untuk menginternalisasikan nilai-nilai karakter yang telah ditetapkan di sekolah dengan melibatkan sumber daya baik internal maupun eksternal sekolah. Temuan penelitian terkait perencanaan PPK ini sejalan dengan pendapat Surawati \& Suasthi (2019) bahwa program PPK yang dilaksanakan di sekolah perlu dirancang dengan mengintegrasikan, memperdalam, memperluas, dan sekaligus menyelaraskannya dengan berbagai program dan kegiatan pendidikan karakter yang sudah dilaksanakan sampai sekarang. Dalam hubungan tersebut pengintegrasian antara lain dapat berupa pemaduan kegiatan kelas, luar kelas di sekolah, dan luar sekolah (masyarakat/komunitas); pemaduan kegiatan intrakurikuler, kokurikuler, dan ekstrakurikuler.

\section{Pengorganisasian Program PPK}

Berdasarkan hasil temuan penelitian diketahui bahwa pengorganisasian dalam manajemen program PPK dilakukan dengan menetapkan struktur pengelola program PPK serta penetapan tugas dan tanggung jawab dari masing-masing personil yang terlibat dalam struktur kepengelolaan program tersebut. Struktur pengelola Program PPK di SMK Karsa Mulya terdiri atas: Kepala 
sekolah sebagai penanggung jawab program PPK sekolah, Tim Pengembang PPK sebagai pihak yang bertangggung jawab dalam menetapkan nilai-nilai karakter yang akan dikembangkan serta bertanggung jawab dalam mengawal keterlaksanaan seluruh program PPK, Koordinator PPK terintegrasi dalam pembelajaran yang bertanggung jawab dalam keterlaksanaan integrasi nilainilai karakter dalam proses pembelajaran, Koordinator PPK terintegrasi dalam kegiatan ekstrakurikuler yang bertanggung jawab dalam keterlaksanaan integrasi nilai-nilai karakter dalam seluruh kegiatan ekstrakurikuler, Koordinator budaya sekolah yang bertanggung jawab dalam berbagai kegiatan pengembangan budaya sekolah., serta serta guru dan tenaga kependidikan lainnya sebagai pelaksana kegiatan.

Penetapan struktur pengelolaan program PPK beserta tugas dan tanggung jawab dari masing-masing personil yang terlibat dalam kepengelolaan program tersebut sejalan dengan pendapat Fattah (1996) bahwa pengorganisasian merupakan suatu proses membagi kerja ke dalam tugas-tugas kecil, membebankan tugas-tugas itu kepada orang sesuai dengan kemampuannya, dan mengalokasikan sumber daya serta mengkoordinasikannya dalam rangka efektifitas pencapaian tujuan organisasi. Perihal senada juga dijelaskan Handoko (2017) bahwa pengorganisasian merupakan proses dan kegiatan untuk: (1) penentuan sumber daya-sumber daya dan kegiatankegiatan yang dibutuhkan untuk mencapai tujuan organisasi, (2) perancangan dan pengembangan suatu organisasi atau kelompok kerja yang dapat membawa hal-hal tersebut ke arah tujuan, (3) penugasan tanggungjawab tertentu, dan (4) mendelegasikan wewenang yang diperlukan kepada individu-individu untuk melaksanakan tugas-tugasnya. Fungsi pengorganisasian ini menciptakan struktur formal di mana pekerjaan ditetapkan, dibagi, dan dikoordinasikan.

\section{Pelaksanaan Program PPK}

Berdasarkan hasil temuan penelitian diketahui bahwa pelaksanaan dalam manajemen program PPK dilakukan melalui: (a) PPK terintegrasi dalam pembelajaran dilaksanakan oleh semua guru sesuai dengan mata pelajaran yang diampunya dengan mengimplementasikan proses pembelajaran yang mengintegrasikan nilai-nilai karakter yang telah ditetapkan sekolah serta dalam pengelolaan kelas. Pengintegrasikan nilai-nilai karakter tersebut dilaksanakan dalam setiap tahapan pembelajaran, mulai dari kegiatan pendahuluan, kegiatan inti, dan penutup yang menyisipkan nilai-nilai karakter; (b) PPK terintegrasi dalam berbagai kegiatan ektrakurikuler dilaksanakan sesuai dengan jadwal yang telah ditetapkan oleh sekolah. Pengintegrasian nilai-nilai karakter terhadap berbagai kegiatan ekstrakurikuler dilakukan oleh pembina masing-masing kegiatan ekstrakurikuler dengan penyampaian materi diawal kegiatan dan dalam praktik dari masing-masing kegiatan ekstrakurikuler. Semua kegiatan ekstrakurikuler seperti pramuka maupun kegiatan lainnya yang disesuaikan dengan minat dan bakat peserta didik menyisipkan nilai-nilai karakter yang telah ditetapkan sekolah; dan (c) kegiatan pembiasaan diri yang telah menjadi budaya sekolah dilaksanakan secara rutin dan terprogram. Dalam pelaksanaannya, kegiatan pembiasaan diri ini dimonitoring oleh Koordinator budaya sekolah, Tim pengembang program PPK serta guru-guru yang piket. Semua personil yang terlibat dalam kegiatan pembiasaan diri ini bukan hanya sekedar mengawasi jalannya proses pembiasaan atau budaya sekolah, namun bertindak dan berperilaku melalui memberikan contoh dan keteladanan bagi seluruh peserta didik.

Temuan penelitian ini sejalan dengan pendapat Suwartini (2017) bahwa pembentukan karakter dikembangkan melalui tahap pengetahuan (knowing), pelaksanaan (acting), dan kebiasaan (habit). Karakter tidak terbatas pada pengetahuan saja. Seseorang yang memiliki pengetahuan kebaikan belum tentu mampu bertindak sesuai dengan pengetahuanya, jika tidak terlatih (menjadi kebiasaan) untuk melakukan kebaikan tersebut. Karakter juga menjangkau wilayah emosi dan kebiasan diri. Dengan demikian diperlukan tiga komponen yang baik (component of good character) yaitu moral knowing (pengetahuan tentang moral), moral feeling atau perasaan (penguatan emosi) tentang moral, dan moral action atau perbuatan bermoral. Hal ini diperlukan agar peserta didik dan atau warga sekolah lain yang terlibat dalam sistem 
pendidikan tersebut sekaligus dapat memahami, merasakan, menghayati, dan mengamalkan (mengerjakan) nilai-nilai kebajikan.

\section{Pengawasan dan Evaluasi Program PPK}

Berdasarkan hasil temuan penelitian diketahui bahwa pengawasan dalam manajemen program PPK secara formal menjadi tanggung jawab pengelola program PPK sekolah, namun demikian dalam praktiknya pengawasan dalam arti pemantauan juga dilakukan oleh seluruh personil sekolah (guru dan tenaga kependidikan lainnya). Bentuk pengawasan kegiatan PPK secara keseluruhan (terintegrasi dalam pembelajaran, ekstrakurikuler maupun pembiasaan diri) dilakukan oleh Tim Pengembang PPK melalui observasi (pengamatan secara langsung) di kelas, pada saat berlangsungnya kegiatan ekstrakurikuler maupun pembiasaan diri. Tim Pengembang PPK menganalisis dokumen perangkat pembelajaran, pengamatan kegiatan pembelajaran/ekstrakurikuler/pembiasaan diri, melakukan survei kepada siswa, dan wawancara untuk mengetahui berbagai kendala dalam pelaksanaannya; Hal yang ditemukan selama proses pengawasan tersebut berlangsung dicatatat dan dilaporkan kepada Kepala Sekolah selaku penanggung jawab keseluruhan program PPK. Jika ditemukan kendala-kendala dalam pelaksanaannya Kepala Sekolah selaku penanggung jawab pengelolaan program PPK menindaklanjutinya dengan melakukan supervisi kepada Koordinator PPK terintegrasi dalam pembelajaran bersama para guru, Koordinator PPK terintegrasi dalam kegiatan esktrakurikuler dan pelaksananya, dan Koordinator budaya sekolah dan dan pelaksananya seminggu 2 kali melalui supervisi langsung maupun analisis dokumen laporan pelaksanaan program PPK. Temuan penelitian terkait pengawasan program PPK ini sejalan dengan pendapat Amtu (2013) bahwa pengawasan merupakan suatu proses pengukuran dan penilaian tingkat pengelolaan kerja personil dan tingkat efisiensi penggunaan sarana kerja dalam memberikan kontribusi pada pencapaian tujuan organisasi. Pengawasan dilakukan untuk melakukan tindakan korektif jika ditemukan berbagai peyimpangan dalam pelaksanaan suatu kegiatan melalui proses pemantauan, penilaian dan pelaporan rencana atas pencapaian tujuan yang telah ditetapkan sebagai bentuk tindakan korektif guna penyempurnaan lebih lanjut dari berbagai berbagai kendala yang ditemui dalam pelaksanaan (Usman, 2013).

Setelah dilaksanakannya kegiatan pengawasan tahap selanjutnya adalah melaksanakan evaluasi program PPK. Hasil temuan penelitian tentang evaluasi program PPK sebagai langkah selanjutnya setelah dilaksanakannya kegiatan pengawasan dilakukan dengan mengadakan rapat rutin disetiap akhir semester dan akhir tahun. Dalam rapat evaluasi program PPK tersebut, seluruh pengelola program PPK mengolah dan menganalisis data laporan hasil kegiatan pengawasan yang telah dikumpulkan selama kegiatan pengawasan berlangsung dan mengambil keputusan untuk langkah-langkah perbaikan perlaksanaan program PPK di masa mendatang. Berdasarkan hasil evaluasi diketahui bahwa secara keseluruhan program PPK di SMK Karsa Mulya dapat dikatakan cukup baik terlaksana. Seluruh pelaksana program PPK dari ketiga kegiatan program PPK tersebut dapat melaksanakan tugas dan kewajibannya dengan baik, termasuk pula terjadi perubahan yang cukup signifikan dari perilaku positif peserta didik secara umum; hanya sebagian kecil peserta didik yang masih menunjukkan perilaku-perilaku yang belum mencerminkan karakter sebagaimana yang diharapkan. Tidak dapat dipungkiri bahwa interaksi sosial peserta didik dengan lingkungan sosial tempat tinggalnya lebih lama jika dibandingkan dengan jam sekolah. Hal tersebut cenderung sedikit banyak mempengaruhi perilaku mereka yang terkadang terbawa ke sekolah. Dalam upaya mengatasi hal tersebut, sekolah melakukan koordinasi dengan pihak Komite Sekolah dan orang tua peserta didik untuk mengingatkan pentingnya pelibatan dari para orang tua untuk memantau kehidupan sosial peserta didik di luar jam sekolah, karena sebaik apapun program PPK yang dilakukan sekolah tidak akan tercapai dengan maksimal tanpa dukungan dari para orang tua. Temuan penelitian terkait evaluasi program PPK ini sejalan dengan pendapat Wirawan (2012) bahwa evaluasi merupakan suatu riset untuk mengumpulkan, menganalisis, dan menyajikan informasi yang bermanfaat mengenai objek evaluasi selanjutnya 
menilainya dan membandingkannya dengan indikator evaluasi dan hasilnya dapat digunakan untuk mengambil keputusan mengenai objek evaluasi tersebut. Dalam konteks pelaksanaan suatu program sekolah, dilakukan untuk mengetahui pencapaian tujuan program dengan langkah mengetahui keterlaksanaan kegiatan program (Arikunto \& Jabar, 2009). Evaluasi program diartikan sebagai proses pencarian informasi, penemuan informasi dan penetapan informasi yang dipaparkan secara sistematis tentang perencanaan, nilai, tujuan, manfaat, efektifitas dan kesesuaian sesuatu dengan kriteria dan tujuan yang telah ditetapkan. Tujuan evaluasi program adalah untuk memberikan rekomendasi sebagai bahan pertimbangan dalam menentukan keputusan atas program yang dilaksanakan, dan manfaatnya adalah adanya keputusan yang tepat sesuai dengan hasil evaluasi (Munthe, 2015).

\section{Faktor Pendukung dan Kendala dalam Manajemen Program PPK}

Berdasarkan hasil temuan penelitian diketahui bahwa faktor pendukung dalam manajemen program PPK di SMK Karsa Mulya Palangka Raya, meliputi: (1) komitmen yang kuat dari seluruh personil sekolah untuk mengawal jalannya program PPK, (2) dukungan finansial dan non finansial dari pihak yayasan, (3) dukungan finansial dan non finansial dari komite sekolah, serta (3) sarana dan prasarana sekolah yang memadai untuk mendukung keterlaksanaan berbagai program PPK. Sedangkan faktor yang menjadi kendala dalam manajemen program PPK adalah terkait terbatasnya kemampuan sekolah untuk melakukan pemantauan kehidupan sosial peserta didik di luar jam sekolah. Dengan status sosial ekonomi orang tua peserta didik yang cukup heterogen serta lingkungan masyarakat yang majemuk tentu sedikit banyak akan memberikan "warna" perilaku yang bertolak belakang dengan nilai-nilai karakter yang telah dikembangkan di sekolah. Namun demikian untuk mengantisipasi hal tersebut, dalam setiap pertemuan dengan komite sekolah, pihak sekolah senantiasa mengingatkan pentingnya pelibatan dari para orang tua untuk memantau kehidupan peserta didik di luar jam sekolah, karena sebaik apapun program PPK yang dilakukan sekolah tidak akan tercapai dengan maksimal tanpa dukungan dari para orang tua.

\section{SIMPULAN}

Berdasarkan hasil penelitian dan pembahasan dapat disimpulkan bahwa pelaksanaan Program PPK dalam upaya menumbuhkembangkan karakter peserta didik yang dilaksanakan melalui 3 (tiga) bentuk kegiatan yaitu: PPK terintegrasi dalam pembelajaran, PPK terintegrasi dalam kegiatan ekstrakurikuler dan Pembiasaan diri yang dikelola dengan baik melalui penerapan fungsi-fungsi manajemen meliputi: perencanaan program PPK, pengorganisasian program PPK, pelaksanaan program PPK, serta pengawasan dan evaluasi program PPK, secara efektif dapat menumbuhkembangkan karakter peserta didik dan menjadikan SMK Karsa Mulya sebagai salah satu sekolah menengah atas kejuruan swasta yang berhasil dalam mengimplemtasikan PPK di Provinsi Kalimantan Tengah (LPMP).

\section{UCAPAN TERIMA KASIH}

Ucapan terima kasih penulis sampaikan kepada pihak SMK Karsa Mulya Palangka Raya yang telah memberikan izin dan kemudahan selama proses penelitian ini berlangsung, serta Redaksi Equity in Education Journal (EEJ) yang telah memberikan kesempatan artikel ini dapat terpublikasikan.

\section{DAFTAR PUSTAKA}

Amtu, O. (2013). Manajemen Pendidikan di Era Otonomi Daerah. Bandung: Alfabeta. Arikunto, S., \& Jabar, C. S. A. (2009). Evaluasi Program Pendidikan:Pedoman Teoretis Praktis bagi Mahasiswa dan Praktisi Pendidikan. Jakarta: Bumi Aksara.

Fattah, N. (1996). Landasan Manajemen Pendidikan. Cetakan VII. Bandung: PT Remaja Rosdakarya. 
Handoko, T. H. (2017). Manajemen. Edisi Kedua. Yogyakarta: BPFE.

Hasibuan, M. S. P. (2011). Manajemen: Dasar, Pengertian dan Masalah. Jakarta: Bumi Aksara. Isnaini, R. L. (2016). Penguatan Pendidikan Karakter Siswa melalui Manajemen Bimbingan dan Konseling Islam. Jurnal Manajemen Pendidikan Islam, 1(1).

Kementerian Pendidikan dan Kebudayaan (Kemendikbud). (2020). Karakter sebagai Poros Pendidikan. Diterima dari https://cerdasberkarakter.kemdikbud.go.id/q-a/.

Maisaro, A., Wiyono, B. B., \& Arifin, I. (2018). Manajemen Program Penguatan Pendidikan Karakter di Sekolah Dasar. Jurnal Manajemen dan Supervisi Pendidikan, 1(3).

Miles, M. B., \& Huberman, A. M. (2005). Qualitative Data Analysis (terjemahan). Jakarta: UI Press.

Mulyono, M. A. (2010). Manajemen Administrasi dan Organisasi Pendidikan. Jogjakarta: ArRuzz Media.

Munthe, A. P. (2015). Pentingya Evaluasi Program di Institusi Pendidikan: sebuah Pengantar, Pengertian, Tujuan dan Manfaat. Scholaria, 5(2).

Peraturan Presiden (Perpres) Nomor 87 Tahun 2017 tentang Penguatan Pendidikan Karaker

Purwadhi. (2018). Peranan Etika Profesi Pendidik dalam Mewujudkan Karakter Bangsa. Atikan, $8(2)$.

Raharjo, S. B. (2010). Pendidikan Karakter sebagai Upaya Menciptakan Akhlak Mulia. Jurnal Pendidikan dan Kebudayaan, 16(3).

Sudjana, S. 2004. Manajemen Program Pendidikan (untuk Pendidikan Nonformal dan Pengembangan Sumber Daya Manusia). Bandung: Falah Production.

Sugiyono. (2014). Metodologi Penelitian Pendidikan: Pendekatan Kuantitatif, Kualitatif, dan $R \& D$. Bandung: Alfabeta.

Surawati, N. M., \& Suasthi, I. G. A. (2019). Integrasi Penguatan Pendidikan Karakter (PPK) dalam Penyusunan Perangkat Pembelajaran Pendidikan Agama Hindu di Sekolah Dasar. Widyanatya, 1(1). Doi: https://doi.org/10.32795/widyanatya.v1i1.268.

Suwartini, S. (2017). Pendidikan Karakter dan Pembangunan Sumber Daya Manusia Berkelanjutan. Trihayu: Jurnal Pendidikan ke-SD-an, 4(1).

Undang-Undang Nomor 20 Tahun 2003 tentang Sistem Pendidikan Nasional.

Usman, H. (2013). Manajemen: Teori, Praktik dan Riset Pendidikan. Jakarta: Bumi Aksara.

Wirawan. (2011). Evaluasi: Teori, Model, Standar, Aplikasi dan Profesi. Jakarta: Rajagrafindo Persada. 